\title{
The Effect of Training, Information Technology, Intellectual and Emotional Intelligence on Teacher's Performance
}

\author{
Kusni INGSIH ${ }^{1}$, Agus PRAYITNO ${ }^{2}$, Dwi Eko WALUYO ${ }^{3}$, Suhana SUHANA ${ }^{4}$, Shujahat ALI ${ }^{5}$
}

Received: September 01, 2020 Revised: October 26, 2020 Accepted: November 05, 2020

\begin{abstract}
The performance of a teacher has an important role in the success of education in general. This study aims to determine the factors that affect the decline in teacher performance in one of the junior secondary schools in Indonesia. Based on the literature review, four exogenous variables were identified, namely, training, utilization of information technology, intellectual intelligence, and emotional intelligence. This study uses primary data, collected from a questionnaire distributed to respondents. The questionnaire items are measured using a Likert scale. The sample in this study were all teachers at MTS Darul Falah Sirahan, totaling 32 people. The analysis technique used in testing the hypothesis of this study is multiple regression analysis. Statistical product and service solutions are used as analysis tools. The results of this study indicate that only the variable 'utilization of information technology' has a positive and significant effect. However, the variables 'training,' 'intellectual intelligence,' and 'emotional intelligence' did not have a significant effect. This finding contradicts the literature in general. Therefore, this study recommends improving training methods, both those carried out internally by schools and by related agencies, and schools still need to optimize guidance and potential for teacher's intelligence in improving performance.
\end{abstract}

Keywords: Teacher Performance, Training, Information Technology

JEL Classification Code: J00, J24, M53

\section{Introduction}

The performance of a teacher has an important role in the success of education in general. The problem, according

${ }^{1}$ First Author and Corresponding Author. Lecturer, Management Department, Faculty of Economic and Business, University of Dian Nuswantoro, Indonesia [Postal Address: Jl. Nakula I No. 5-11, Semarang, Central Java, 50131, Indonesia]

Email: kusni.ingsih@dsn.dinus.ac.id ; sekretariat@dinus.ac.id

${ }^{2}$ Lecturer, Management Department, Faculty of Economic and

Business, University of Dian Nuswantoro, Indonesia.

Email: agus.prayitno@dsn.dinus.ac.id.

${ }^{3}$ Lecturer, Management Department, Faculty of Economic and

Business, University of Dian Nuswantoro, Indonesia.

Email: dwi.eko.waluyo@dsn.dinus.ac.id.

${ }^{4}$ Lecturer, Management Department, Faculty of Economic and

Business, University of Unisbank, Indonesia.

Email: suhana@edu.unisbank.ac.id.

${ }^{5}$ Mirpur University of Science and Technology, Mirpur AJK, University of Science and Technology of China, Hefei, China.

Email: shujahat@must.edu.pk

(c) Copyright: The Author(s)

This is an Open Access article distributed under the terms of the Creative Commons Attribution Non-Commercial License (https://creativecommons.org/licenses/by-nc/4.0/) which permits unrestricted non-commercial use, distribution, and reproduction in any medium, provided the original work is properly cited. to various studies, is that teachers in Indonesia seem unable to show adequate performance (Muhammad, 2015; Tanang \& Abu, 2014). Teacher's performance in learning includes understanding the nature and characteristics of students and their development, understanding the concept of learning, mastering several appropriate learning methods, and proper evaluation methodologies (Elliott, 2015; Pope, 2019; Taylor \& Tyler, 2012). Several studies show that to improve performance, one method that can be used is to optimize training (Nielsen, 2010; Vesely, et al., 2014). Training refers to a series of activities that provide opportunities to acquire and improve work-related skills. Several studies conducted in Indonesia also show that training has a positive correlation with performance (Constantine et al., 2009; Tanang \& Abu, 2014). This is in line with the research findings of Wolor et al. (2020) that show that e-training has a positive effect on employee's performance.

In the modern era, a factor that is no less important is information technology. Several studies have argued that technology has a positive influence on improving the general performance, including teacher's performance (Tran et al., 2020; Ambarwati et al., 2020; Palao et al., 2015; Forehand, 2012; Means, 2010). For example, Betrancourt (2012) 
suggests that information technology in the form of visuals can increase the effectiveness of learning. Meanwhile, it is common to find that using the Internet will make it easier for teachers and students to find references. The convenience and other advantages of information technology should be used by every teacher to improve performance, which in turn improves the quality of learning itself.

Furthermore, several studies suggest that one of the factors that influence teacher's performance is intellectual intelligence (Côté \& Miners, 2006; Woolley et al., 2010). Jaeggi et al., 2008; Von et al., 2011) find that intellectual intelligence has a positive effect both simultaneously and partially on performance. However, other findings from Yani and Istiqomah (2016) show that intellectual intelligence has a negative and significant impact on performance. Based on several existing studies, it can be seen that the effect of intellectual intelligence on performance in general still has room for debate. However, even though it is still biased for different samples and subjects, it can be concluded that intellectual intelligence has the potential to improve performance if it can be optimized as an exogenous variable.

Still related to intelligence, another form of intelligence that is often taken into account is emotional intelligence. Emotional intelligence in modern organizations is the foremost task among other leadership tasks to move collective emotions in a positive direction. In simple terms, emotional intelligence is the ability to control itself (Côté \& Miners, 2006; Jordan \& Troth, 2004). Joseph \& Newman (2010; Lam \& Kirby (2002; Lyons \& Schneider (2005) found that emotional intelligence had a simultaneous and partial effect on performance. Not much different from intellectual intelligence, several studies also show that sometimes emotional intelligence does not have a direct effect on performance in general. However, it is the same as the argument that this study puts forward on the intellectual intelligence factor, something that is debatable. Its scholarship actually has the potential as a driving variable to improve performance.

MTs Darul Falah Sirahan, as a formal education institution at the junior high school level, actively supervises teacher's performance every year. As a result of the supervision carried out, the principal said that there had been a decline in teacher's performance in the last three years. Supervision carried out during the 2016/2017 school year showed that teacher's performance received a high score of 97 . In the 2017/2018 school year, it received a score of 91 and in the $2018 / 2019$ school year, it received a score of 85 . Based on the existing data trends, it is certainly necessary to evaluate what is needed to optimize performance. Based on the existing problems and previous research, the purpose of this study is to understand the significance of the effect of training, the use of information technology, intellectual intelligence, and emotional intelligence on teacher's performance at MTs Darul Falah Sirahan.

\section{Literature Review}

The development of an organization is closely related to job training. With training, an organization can find out new elements that become evaluation materials to develop according to new rules and regulations. In the world of education, every year the government has new regulations. Through training, it is hoped that these regulations can be implemented by schools as desired by the government. Teachers' knowledge of government policies must also be updated so that teacher's performance can improve in accordance with existing regulations. Research conducted by Kunartinah and Sukoco (2010) find that training has a positive effect on teacher's performance. They mediate between the variables of education, training, organizational learning, teacher's competence, and performance. Of the variables tested, all of them have an effect on performance, but only training has a direct effect without mediation. Hasanah (2010) concluded that training can improve teacher's performance. Training greatly affects teacher's performance, so that teachers must be provided with the opportunity to develop themselves through training organized by related institutions (Constantine et al., 2009; Nielsen, 2010; Vesely et al., 2014).

Information technology is part of the standard operation of an organization. The rapid development of technology is no longer a special item. Schools, as a means of introducing someone to the development of science, are expected to not be left behind in information technology. For the smoothness of the teaching and learning process, teachers are also expected to be able to master information technology. Rachmawaty (2014) states that the use of information technology is a means to support/encourage organizations to achieve organizational goals. Information technology can be used effectively if members of the organization can use the technology properly. Research states that the use of information technology has a strong influence on teacher's performance. In addition, if teachers have used information technology well, the use of information technology can support better performance (Means, 2010; Smith, 2013).

The effectiveness of an organization depends on the quality of human resources available. No matter how sophisticated the work program and equipment the organization has, if it is not operated with a workforce who has competence and motivation, it will only be redundant (Hendriani \& Gunarsih, 2013). Research conducted by Hendriani and Garnasih (2013) also found that intellectual intelligence has a positive effect on teacher's performance. The literature found that there is a positive and significant influence of emotional intelligence on teacher's performance. In the 
teaching-learning process, teachers as educators should be able to understand themselves and others, especially students. The ability to understand yourself and others is needed to make it easier to provide material to students. Teachers are also wiser in solving the problems of students who have special abilities. The existence of students who are stubborn, naughty, or having insufficient understanding can be handled as well as possible with the teacher's emotional intelligence (Brackett et al., 2012; Isenbarger \& Zembylas, 2006).

\section{Research Methods and Materials}

A description of the relationship between training, utilization of information technology, intellectual intelligence, and emotional intelligence and teacher's performance is made into a conceptual framework. Training, utilization of information technology, intellectual intelligence, and emotional intelligence are independent variables, while teacher's performance is the dependent variable. In more detail, the conceptual framework of this study is shown in Figure 1.

This study used a questionnaire as an instrument consisting of 27 statement items, including five items for teacher's performance variables, six items to measure training variables, six items to measure information technology utilization variables, five items to measure intellectual intelligence variables and five items to measure emotional intelligence variables. This study used a Likert scale. The sample in this study was the teacher population at MTS Darul Falah Sirahan totaling 32 people. The analysis technique used in testing the hypotheses was multiple regression analysis.

$$
\mathrm{TP}=\alpha+\beta_{1} \mathrm{TR}+\beta_{2} \mathrm{IT}+\beta_{3} \mathrm{II}+\beta_{4} \mathrm{EI}+\mathrm{e}
$$

Note: TP = teachers' performance; TR = training; IT = technology information; II = intellectual intelligence; $\mathrm{EI}=$ emotional intelligence $; \alpha=$ intercept; $\beta=$ regression coefficient; e = error disturbance.

\section{Result and Discussion}

The data from the questionnaire show that respondents with a service period of more than 10 years account for more than $50 \%$. Based on gender, employees who work at MTs Darul Falah Sirahan, are dominated by men $(71.88 \%)$. This indicates a high level of male population working at MTs Darul Falah Sirahan. Based on the educational background, most of the teachers have an S1 background, namely, 30 people and S2 as many as two people. These data indicate that the education of teachers at MTs Darul Falah has met the government's criteria, namely, as SMP/ MTs teachers have at least a S1 education background.

Indicators to provide learning evaluations get a score below 4. These results indicate that in general the teachers in the sample believed that their performance was good. Generally, the training variable gets an average score of 4 or is in a good category. Indicators of increasing knowledge and delivery of material get scores with fairly good criteria, while other indicators get good criteria. This simple data analysis indicates that the training variable still allows for more optimization in improving performance.

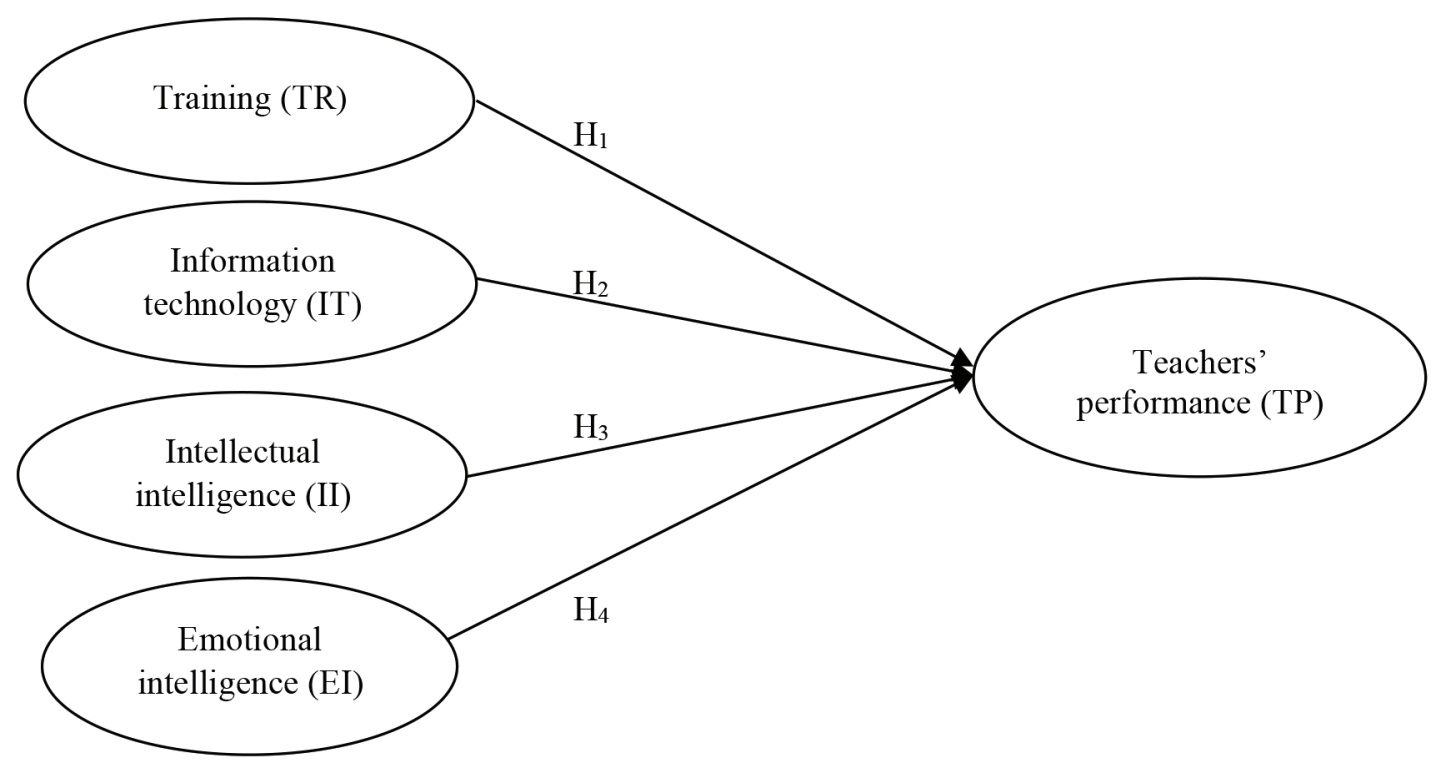

Figure 1: Conceptual framework 
The majority of indicators of the use of information technology show a score above 4 , only the indicators of feeling comfortable in using information technology get a score below 4. In general, the variable of the use of information technology got a score of 4.37 or was in a good category. This study underlines the feeling of comfort indicator. This is because this indicator has the lowest value compared to other indicators for the variable use of information technology. It is very possible that the indicators are low due to the lack of basic mastery of information technology, so teachers' lack confidence in using information technology. Another possibility is that some teachers have the perception that not all subjects can be supported by the use of information technology.

The intellectual intelligence variable gets a score of 4.16 or is in a good category, but there are two indicators, namely, indicators of analytical and critical thinking and indicators of logical thinking skills that score below 4. This data illustrates that teachers still need to improve their analytical and logical thinking skills in planning, implementing, and evaluating the learning process. Meanwhile, compared to the other four variables, the emotional intelligence variable ranked the lowest with an average score of 3.75 or got a fairly good category. This data indicates that, assuming emotional intelligence can improve teacher's performance, the schools sampled in this study need to strengthen emotional intelligence in the programs. In terms of each indicator, indicators of self-awareness, self-regulation, and motivation, each got a score of $3.63 ; 3.50$ and 3.53 , respectively, or categorized as quite good. The data indicates that teachers do not have a strong motivation to improve self-quality.

The effect of training income on the use of information technology, intellectual intelligence, and emotional intelligence on teacher's performance can be seen in Table 1. Based on the table, the multiple linear regression equation is obtained as follows: teacher's performance $=0.026+$ 0.023 (training) +0.857 (information technology utilization) + 0.202 (intellectual intelligence) - 0.194 (emotional intelligence). Referring to the significance value, only the variable of information technology utilization is significant with a confidence level of 5\%. Next, the Anova test presented in Table 2 shows a significance level of 0.000 , which means that the model built is generally significant. The coefficient of determination as in Table 3 shows that the independent variable is able to explain the dependent variable by $83.9 \%$, while the rest is explained by other variables.

Table 1: Result of multiple regression

\begin{tabular}{|c|c|c|c|c|c|}
\hline \multicolumn{6}{|c|}{ Coefficients $^{a}$} \\
\hline \multirow{2}{*}{ Model } & \multicolumn{2}{|c|}{ Unstandardized Coefficients } & \multirow{2}{*}{$\begin{array}{c}\text { Standardized Coefficients } \\
\text { Beta }\end{array}$} & \multirow{2}{*}{$\mathbf{t}$} & \multirow{2}{*}{ Sig. } \\
\hline & B & Std. Error & & & \\
\hline (Constant) & ,026 & ,374 & & ,068 & ,946 \\
\hline Training & ,023 & ,086 & ,023 & ,262 & ,795 \\
\hline Technology information & ,944 & ,110 & ,857 & 8,541 &, 000 \\
\hline Intellectual Intelligence & ,174 & , 104 & ,202 & 1,677 &, 105 \\
\hline Emotional Intelligence &,- 152 & ,085 &,- 194 & $-1,804$ & ,082 \\
\hline
\end{tabular}

Table 2: Anova test

\begin{tabular}{|l|l|c|c|c|c|c|}
\hline \multicolumn{2}{|c|}{ Model } & Sum of Squares & df & Mean Square & F & Sig. \\
\hline \multirow{3}{*}{1} & Regression & 6,230 & 4 & 1,557 & 41,299 &, $000^{\mathrm{b}}$ \\
\cline { 2 - 6 } & Residual & 1,018 & 27 &, 038 & \\
\cline { 2 - 6 } & Total & 7,248 & 31 & & \\
\hline
\end{tabular}

Table 3: Determination Test

\begin{tabular}{|l|c|c|c|c|c|}
\hline Model & $\mathbf{R}$ & $\mathbf{R}$ Square & Adjusted R Square & Std. Error of the Estimate & Durbin-Watson \\
\hline 1 &, $927^{a}$ &, 860 &, 839 &, 194 & 2,071 \\
\hline
\end{tabular}


Statistically, the training does not affect teacher's performance. At first, this was quite confusing because some of the training that was attended by teachers had no impact on performance. This finding contradicts other research, both theoretically and practically, because training is a common step to improve performance. This finding also contradicts several studies which show that training has a significant positive effect on improving performance (Nielsen, 2010; Pope, 2019; Vesely et al., 2014). The results of additional interviews with Madrasah principals show that the training that has been attended has not been able to be carried out optimally due to the changing curriculum, so that teachers find it difficult to adapt to these changes.

Information technology is proven to have a significant effect on teacher's performance. This means that the better use of information technology will further improve the performance of teachers at MTs Darul Falah Sirahan. The findings of this study are in line with several studies on the role of information technology in various fields including learning. Information technology allows the presentation of material in a more creative and innovative way, so that the material can be more easily accepted by students. Information technology also allows access to reference sources that are more efficient and cost-effective in terms of time and cost (Forehand, 2012; Means, 2010). Therefore, it is natural that information technology has a positive and significant impact on teacher's performance.

Intellectual intelligence in this study does not statistically have a significant effect on teacher's performance. This finding is actually an anomaly, how could intellectual intelligence not have a significant effect on teacher performance? Emotional intelligence statistically has a negative and insignificant effect on teacher's performance. This finding is surprising because a better level of emotional intelligence in general will increase the performance (Lam \& Kirby, 2002; Lyons \& Schneider, 2005). Based on the indicators, is it logical that self-evaluation does not support a teacher's performance? The answer is definitely no. However, this study did not explore this problem because, with a 5\% significance, the emotional intelligence variable was statistically stated as not having a significant effect on the performance variable.

However, additional interviews with the principal can provide a perspective on why this can happen. Teachers who have high intellectual intelligence rarely teach according to the lesson plan. The teacher assumes that, by fixating the learning plan, learning will run monotonously. However, the teacher makes a lesson plan only to meet the administration's requirements, while in the implementation of activities, teacher's creativity is delivered in accordance with the situation and conditions of the class being taught. The answer from the principal looks logical, but if the lesson plan is arranged properly, it can be implemented according to classroom conditions. Therefore, this study suspects that the preparation of learning plans is not compiled according to the correct rules.

Referring to the principal's statement regarding the teacher's assumption of not paying too much attention to the importance of lesson plans, this indicates that the teachers in these schools do not really understand the role of lesson plans. Therefore, strong leadership from the principal is needed. Referring to the results of data analysis, which shows that research has no effect on performance, also strengthens the notion that the training held and attended by teachers has not touched on substantial basic aspects. This study recommends that teachers should be provided with substantial training on learning and lesson planning rather than administrative training. This training can also be aimed at optimizing the intellectual and emotional intelligence of teachers.

\section{Conclusion}

This study concludes that statistically, performance in the schools in the study is only influenced by the use of information technology, while the variables of training, intellectual intelligence, and emotional intelligence have no significant effect. This finding contradicts the literature in general. Therefore, this study recommends improving training methods, both those carried out internally by schools and by related institutions. Meanwhile, for intellectual and emotional intelligence, this study recommends that schools strengthen lesson plans to optimize the intelligence possessed by teachers.

\section{References}

Ambarwati, R., Harja, Y. D., Thamrin, S. (2020). The role of facilitating conditions and user habits: a case of Indonesian online learning platform. Journal of Asian Finance, Economics and Business, 7(10), 481-489. https://doi.org/10.13106/ jafeb.2020.vol7.no10.481

Betrancourt, M. (2012). The animation and interactivity principles in multimedia learning. In: the Cambridge handbook of multimedia learning (pp. 287-296). https://doi.org/10.1017/ cbo9780511816819.019.

Brackett, M. A., Rivers, S. E., Reyes, M. R., \& Salovey, P. (2012). Enhancing academic performance and social and emotional competence with the RULER feeling words curriculum. Learning and Individual Differences, 22(2012), 218-224. https://doi.org/10.1016/j.lindif.2010.10.002.

Constantine, J., Player, D., Silva, T., Hallgren, K., Grider, M., \& Deke, J. (2009). An evaluation of teachers trained through different routes to certification an evaluation of teachers trained through different routes to certification. U.S. Department of Education.

Côté, S., \& Miners, C. T. H. (2006). Emotional intelligence, cognitive intelligence, and job performance. Administrative 
Science Quarterly, 51(2006), 1-28. https://doi.org/10.2189/ asqu.51.1.1.

Elliott, K. (2015). Teacher performance appraisal: More about performance or development? Australian Journal of Teacher Education, 40(9), 102-116. https://doi.org/10.14221/ ajte.2015v40n9.6.

Forehand, M. (2012). Bloom's Taxonomy from Emerging Perspectives on Learning, Teaching and Technology. International Journal of Educational Management, 1-10.

Hasanah, S. D. (2010). The effect of training education (DIKLAT) on teacher leadership and work climate on the performance of elementary school teachers in Babakancikao sub-district, Purwakarta district. Journal of Educational Research, 11(2), 85-96.

Hendriani, S. \& Ganarsih, L. (2013). The influence of intellectual and emotional intelligence on the performance of teachers at SMAN 8 Pekanbaru. Economic Journal, 21(4), 1-10.

Isenbarger, L., \& Zembylas, M. (2006). The emotional labour of caring in teaching. Teaching and Teacher Education, 22(2006), 120-134. https://doi.org/10.1016/j.tate.2005.07.002.

Jaeggi, S. M., Buschkuehl, M., Jonides, J., \& Perrig, W. J. (2008). Improving fluid intelligence with training on working memory. Proceedings of the National Academy of Sciences of the United States of America, 105(19), 6829-6833. https://doi.org/10.1073/ pnas.0801268105.

Jordan, P. J., \& Troth, A. C. (2004). Managing emotions during team problem solving: Emotional intelligence and conflict resolution. Human Performance, 17(2), 195-218. https://doi. org/10.1207/s15327043hup1702_4.

Joseph, D. L., \& Newman, D. A. (2010). Emotional intelligence: an integrative meta-analysis and cascading model. Journal of Applied Psychology, 95(1), 54-78. https://doi.org/10.1037/ a0017286.

Kurtinah \& Sukoco, F. (2010). The influence of education and training, organizational learning on performance with competence as mediation. Journal of Business and Economics, 17(1), 74-84.

Lam, L. T., \& Kirby, S. L. (2002). Is emotional intelligence an advantage? an exploration of the impact of emotional and general intelligence on individual performance. Journal of Social Psychology, 142(1), 133-143. https://doi. org/10.1080/00224540209603891.

Lyons, J. B., \& Schneider, T. R. (2005). The influence of emotional intelligence on performance. Personality and Individual Differences, 39(2005), 693-703. https://doi.org/10.1016/j. paid.2005.02.018.

Means, B. (2010). Technology and education change: focus on student learning. Journal of Research on Technology in Education, 42(3), 285-307. https://doi.org/10.1080/15391523. 2010.10782552 .

Muhammad, A. H. (2015). The influence of competence, motivation, and organisational culture to high school teacher job satisfaction and performance. International Education Studies, 8(1), 38-45. https://doi.org/10.5539/ies.v8n1p38.

Nielsen, S. (2010). Vocational education and training teacher training. The European Training Foundation, 503-512. https:// doi.org/10.1016/B978-0-08-044894-7.00808-3.

Palao, J. M., Hastie, P. A., Cruz, P. G., \& Ortega, E. (2013). The impact of video technology on student performance in physical education. Technology, Pedagogy and Education, (2013), 1-13. https://doi.org/10.1080/1475939X.2013.813404.

Pope, N. G. (2019). The effect of teacher ratings on teacher performance. Journal of Public Economics, 172(2019), 84-110. https://doi.org/10.1016/j.jpubeco.2019.01.001.

Rachmawaty, A. (2014). The effect of the use of information technology on teacher performance at 43 SMP Negeri Bandung. Journal of Information and Communication Technology, 1(1), 26-35.

Smith, N. V. (2013). Face-to-face vs. blended learning: effects on secondary students 'perceptions and performance. Procedia Social and Behavioral Sciences, 89(2013), 79-83. https://doi. org/10.1016/j.sbspro.2013.08.813.

Tanang, H., \& Abu, B. (2014). Teacher professionalism and professional development practices in South Sulawesi, Indonesia. Journal of Curriculum and Teaching, 3(2), 25-42. https://doi.org/10.5430/jct.v3n2p25.

Taylor, E. S., \& Tyler, J. H. (2012). The effect of evaluation on teacher performance. American Economic Review, 102(7), 3628-3651. https://doi.org/10.1257/aer.102.7.3628.

Tran, N., Le, T., Nguyen, L., Hoang, L., Nguyen, T. (2020). Factors influencing technology adoption in Vietnam's education system. Journal of Asian Finance, Economics and Business, 7(10), 347-357. https://doi.org/10.13106/jafeb.2020.vol7. n10.347

Vesely, A. K., Saklofske, D. H., \& Nordstokke, D. W. (2014). EI training and pre-service teacher wellbeing. Personality and Individual Differences, 65(2014), 81-85. https://doi. org/10.1016/j.paid.2014.01.052.

Von S. S., Hell, B., \& Chamorro-Premuzic, T. (2011). The hungry mind: intellectual curiosity is the third pillar of academic performance. Perspectives on Psychological Science, 6(6) 574-588. https://doi.org/10.1177/1745691611421204.

Wolor, C. W., Solikhah, S., Fidhyallah, N. F., Lestari, D. P. (2020). Effectiveness of e-training, e-leadership, and work life balance of employee performance during COVID-19. Journal of Asian Finance, Economics and Business, 7(10), 443-450. https://doi. org/10.13106/jafeb.2020.vol7.no10.443

Woolley, A. W., Chabris, C. F., Pentland, A., Hashmi, N., \& Malone, T. W. (2010). Evidence for a collective intelligence factor in the performance of human groups. Science, 330, 686-688. https:// doi.org/10.1126/science.1193147.

Yani, A. S. \& Istiqomah, A. (2016). The influence of intellectual and emotional intelligence on the performance of employee professionalism as an intervening variable. Media Economic Studies, 19(2), 1-14. 